\title{
Evaluation of Different Parasitological Techniques for Diagnosing Intestinal Parasites in Dogs
}

\author{
Breno Barros de Santana1, Tallys Leandro Barbosa da Silva1, \\ Rafael Antonio Nascimento Ramos ${ }^{2,3}$, Leucio Câmara Alves², \\ Gílcia Aparecida de Carvalho ${ }^{*}$ \\ ${ }^{1}$ Unidade Acadêmica de Garanhuns, Universidade Federal Rural de Pernambuco, Garanhuns, Brazil \\ ${ }^{2}$ Departamento de Medicina Veterinária, Universidade Federal Rural de Pernambuco, Recife, Brazil \\ ${ }^{3}$ Dipartimento di Medicina Veterinaria, Università degli Studi di Bari, Bari, Italy \\ Email: "gilciasilva@yahoo.com.br
}

Received 23 January 2015; accepted 10 February 2015; published 11 February 2015

Copyright (C) 2015 by authors and Scientific Research Publishing Inc.

This work is licensed under the Creative Commons Attribution International License (CC BY). http://creativecommons.org/licenses/by/4.0/

cc) (7) Open Access

\begin{abstract}
Intestinal nematodes are among the most common parasites of dogs, being Toxocara spp. and Ancylostoma spp. threats to public health due to their zoonotic potential. In this study, three parasitological diagnostic techniques for detecting the eggs/oocysts of canine intestinal parasites were evaluated. Fecal samples $(n=285)$ were collected from the environment (i.e. public streets, squares and homes) in Garanhuns, Pernambuco, Brazil. Samples were analyzed using the WillisMollay simple flotation technique, spontaneous sedimentation (Hoffman, Pons and Janer) and modified centrifugal flotation. Among the samples analyzed, 56.49\% (161/285) showed eggs and/or oocysts of intestinal parasites. In particular, 44.21\% (126/285) were detected by the Willis technique, $45.14 \%(121 / 268)$ by centrifugal flotation and $31.57 \%(90 / 285)$ by the Hoffmann technique. The kappa index indicated good concordance between the centrifugal flotation and Willis techniques $(\kappa=0.625)$, whereas fair concordance was observed between Hoffmann and Willis $(\kappa=$ $0.480)$, and between Hoffman and centrifugal flotation $(\kappa=0.433)$. In conclusion, the centrifugal flotation technique showed high sensitivity towards detecting Ancylostoma spp. and Toxocara spp. (the most common parasites in this study) and could be used in association with the Willis technique to obtain safe diagnoses within routine laboratory analysis.
\end{abstract}

\section{Keywords}

Willis-Mollay, Modified Centrifugal Flotation, Hoffman, Dogs, Zoonotic Helminths

\footnotetext{
"Corresponding author.

How to cite this paper: de Santana, B.B., da Silva, T.L.B., Ramos, R.A.N., Alves, L.C. and de Carvalho, G.A. (2015) Evaluation of Different Parasitological Techniques for Diagnosing Intestinal Parasites in Dogs. Open Journal of Veterinary Medicine, 5, 19-24. http://dx.doi.org/10.4236/ojvm.2015.52003
} 


\section{Introduction}

Parasitic diseases are among the most important zoonoses throughout the world and are considered to be a serious threat to socioeconomic equilibrium, particularly in developing countries [1]. For example, parasites that affect dogs, such as the helminths Toxocara spp. and Ancylostoma spp., which are the causative agents of visceral larva migrans (VLM) and cutaneous larva migrans (CLM), respectively, present great sanitary importance [2] [3].

Despite the wide range of therapeutic and prophylactic measures currently available, eggs and oocysts of parasites are commonly detected in the feces of dogs, and their elimination in the environment facilitates transmission to other hosts, including humans [4] [5]. Most of these intestinal parasites (e.g. Toxocara spp., Ancylostoma spp. and Cystoisospora canis) present cosmopolitan distribution, and they are most prevalent in tropical areas with inadequate sanitary conditions [6] [7]. Currently, with increasing dog ownership, the number of people at risk of acquiring parasitic zoonoses is also increasing [2]. However, human infection is not restricted only to the household environment, but comes especially through public places such as squares and streets [8]-[12].

Parasitological diagnostic methods are useful for detecting intestinal parasites through searching for different parasitic forms (e.g. eggs, larvae, oocysts or trophozoites) that are eliminated in feces. Despite improvements in immunological techniques and the advent of molecular tests, parasitological methods are still considered important, particularly because of their simplicity and low cost [13]-[15]. However, since the diagnosis is based on viewing eggs or oocysts, confirmation may in some cases be difficult [6]. In addition, choosing the most suitable method for use within the routine of the diagnostic laboratory may represent an obstacle for efficient diagnosis. Therefore, the aim of this study was to evaluate three different techniques (Willis-Mollay flotation technique; spontaneous sedimentation of Hoffman, Pons and Janer; modified centrifugal flotation) for detecting eggs/oocysts of intestinal parasites in dogs.

\section{Materials and Methods}

\subsection{Sample Collection}

From August 2011 to July 2012, canine fecal samples $(n=285)$ were collected directly from the environment (i.e. public streets, squares and backyards) in the city of Garanhuns, state of Pernambuco, Brazil. The samples collected were put into plastic vials, identified and stored in isothermal boxes at $4^{\circ} \mathrm{C}$ until laboratory processing.

\subsection{Laboratorial Procedures}

All samples were analyzed using three different techniques for detecting eggs and oocysts: 1) Willis-Mollay flotation technique [16]; 2) spontaneous sedimentation of Hoffman, Pons and Janer [17]; 3) modified centrifugal flotation [18]. From here on, and throughout the text, the methods will be referred to as the Willis, Hoffman and centrifugal flotation techniques.

After doing the preparations for each technique, the fecal material was transferred to slides and a drop of Lugol solution (2\%) was added. Finally the slides were covered with cover slips for observations to be made under a microscope at different magnifications $(10 \times$ and $40 \times)$. The eggs and oocysts were identified as previously described [19] [20].

\subsection{Data Analysis}

Kappa concordance analysis was used to compare the results. The Kappa values were interpreted in accordance with [21]. The sensitivity, specificity, positive predictive value (+PV), negative predictive value (-PV) and accuracy were determined taking the Willis technique to be the gold standard [22]. The Bioestat 5.0 and Epi-Info software was used to calculate all parameters.

\section{Results}

Out of 285 samples analyzed, eggs/oocysts of intestinal parasites were detected in $56.49 \%$ (161/285): $44.21 \%$ (126/285) detected through the Willis technique, 45.14\% (121/268) through centrifugal flotation and 31.57\% (90/285) through the Hoffman technique. The overall results regarding infections and coinfections detected using each technique are reported in Table 1. 
Interestingly, Ancylostoma spp. and Toxocara spp. were the parasites most frequently detected, independently of the method used. The average numbers of eggs/oocysts detected by means of all the techniques are reported in Table 2.

Table 1. Infections and co-infections detected in each technique of intestinal parasites in canine fecal samples in the municipality of Garanhuns, PE.

\begin{tabular}{|c|c|c|}
\hline Techniques & Parasites & Positivity $(\% / \mathrm{n})$ \\
\hline \multirow[t]{9}{*}{ Willis-Mollay floating } & Ancylostoma spp. & $76.20 \%(96 / 126)$ \\
\hline & Toxocara spp. & $4.80 \%(06 / 126)$ \\
\hline & Dipyllidium spp. & $1.70 \%(02 / 126)$ \\
\hline & Ancylostoma spp. + Toxocara spp. & $8.73 \%(11 / 126)$ \\
\hline & Dipyllidium spp. + Toxocara spp. & $2.55 \%(03 / 126)$ \\
\hline & Ancylostoma spp. + Dipyllidium spp. & $2.55 \%(03 / 126)$ \\
\hline & Ancylostoma spp. + Isospora spp. & $1.70 \%(02 / 126)$ \\
\hline & $\begin{array}{c}\text { Toxocara spp. }+ \text { Isospora spp. }+ \text { Dipyllidium spp. } \\
+ \text { Ancylostoma } \text { spp. }+ \text { Trichuris spp. }\end{array}$ & $0.85 \%(1 / 126)$ \\
\hline & $\begin{aligned} \text { Ancylostoma spp. } & + \text { Thichuris spp. }+ \text { Giardia spp. } \\
& + \text { Isospora } \mathrm{spp} .\end{aligned}$ & $0.85 \%(1 / 126)$ \\
\hline \multirow[t]{7}{*}{ Modified centrifugal flotation } & Ancylostoma spp. & $80.16 \%(97 / 121)$ \\
\hline & Toxocara spp. & $5.77 \%(07 / 121)$ \\
\hline & Dipyllidium spp. & $0.83 \%(01 / 121)$ \\
\hline & Ancylostoma spp. + Toxocara spp. & $9.09 \%(11 / 121)$ \\
\hline & $\begin{array}{l}\text { Ancylostoma spp. }+ \text { Dipyllidium spp. } \\
\text { Ancylostoma spp. }+ \text { Strongyloides spp. }\end{array}$ & $0.83 \%(01 / 121)$ \\
\hline & Toxocara spp. + Isospora spp. & $0.83 \%(01 / 121)$ \\
\hline & Ancylostoma spp + Isospora spp. & $0.83 \%(01 / 121)$ \\
\hline \multirow[t]{7}{*}{$\begin{array}{l}\text { Spontaneous sedimentation of } \\
\text { Hoffman, Pons and Janer }\end{array}$} & Ancylostoma spp. & $75.56 \%(68 / 90)$ \\
\hline & Toxocara spp. & $8.89 \%(08 / 90)$ \\
\hline & Dipyllidium spp. & $2.22 \%(02 / 90)$ \\
\hline & Ancylostoma spp. + Toxocara spp.. & $8.89 \%(08 / 90)$ \\
\hline & Ancylostoma spp. + Dipyllidium spp. & $2.22 \%(02 / 90)$ \\
\hline & Ancylostoma spp. + Trichuris spp & $1.11 \%(01 / 90)$ \\
\hline & Ancylostoma spp. + Toxocara spp. + Trichuris spp. & $1.11 \%(01 / 90)$ \\
\hline
\end{tabular}

Table 2. Absolute and relative frequency, number mean of eggs and standard deviation of intestinal parasites detected in fecal samples from dogs in the municipality of Garanhuns, PE.

\begin{tabular}{cccccccccccccccccc}
\hline & \multicolumn{4}{c}{ Willis-Mollay floating } & \multicolumn{4}{c}{ Modified centrifugal flotation } & \multicolumn{5}{c}{ Hoffman, Pons and Janer } \\
\cline { 2 - 6 } & $\mathrm{AF}(\mathrm{n})$ & $\mathrm{Mn}$ & $\mathrm{Mx}$ & $\bar{x} \pm \mathrm{SD}$ & $\mathrm{RF}(\%)$ & $\mathrm{AF}(\mathrm{n})$ & $\mathrm{Mn}$ & $\mathrm{Mx}$ & $\bar{x} \pm \mathrm{SD}$ & $\mathrm{RF}(\%)$ & $\mathrm{AF}(\mathrm{n})$ & $\mathrm{Mn}$ Mx & $\bar{x} \pm \mathrm{SD}$ & $\mathrm{RF}(\%)$ \\
\hline $\begin{array}{c}\text { Ancylostoma } \\
\text { spp. }\end{array}$ & 1595 & 0 & 113 & $5.96 \pm 0.9$ & 88.7 & 2171 & 0 & 200 & $8.101 \pm 1.4$ & 79.1 & 392 & 0 & 45 & $1.38 \pm 0.2$ & 63.7 \\
$\begin{array}{c}\text { Toxocara } \\
\text { spp. }\end{array}$ & 196 & 0 & 55 & $0.7 \pm 0.3$ & 10.9 & 541 & 0 & 336 & $2.02 \pm 1.3$ & 19.7 & 220 & 0 & 72 & $0.77 \pm 0.3$ & 35.7 \\
$\begin{array}{c}\text { Trichuris } \\
\text { spp. }\end{array}$ & 06 & 0 & 06 & $0.02 \pm 0.01$ & 0.33 & 06 & 0 & 06 & $0.02 \pm 0.02$ & 0.22 & 03 & 0 & 02 & $0.01 \pm 0.007$ & 0.4 \\
$\begin{array}{c}\text { Strongyloides } \\
\text { spp. }\end{array}$ & - & - & - & - & - & 24 & 0 & 17 & $0.08 \pm 0.06$ & 0.88 & - & - & - & - & - \\
$\quad$\begin{tabular}{c} 
Total (n) \\
\hline
\end{tabular} & 1791 & - & - & - & 100 & 2742 & - & - & - & 100 & 617 & - & - & - & 100 \\
\hline
\end{tabular}


From the kappa analysis, the following results were obtained: Willis versus centrifugal flotation $(\kappa=0.625$; $\mathrm{P}$ $<0.001)$ : good concordance; Willis versus Hoffman, $(\kappa=0.480 ; \mathrm{P}<0.001)$ : fair concordance; centrifugal flotation versus Hoffman $(\kappa=0.433 ; \mathrm{P}<0.001)$ : fair concordance. The sensitivity, specificity, $+\mathrm{PV},-\mathrm{PV}$ and accuracy values are shown in Table 3 .

\section{Discussion}

In this study, three different parasitological diagnosis techniques (Willis, Hoffman and centrifugal flotation techniques) were evaluated. The results demonstrated different performances between the methods evaluated, especially considering the percentages of positive of $44.21 \%(126 / 285), 45.14 \%(121 / 268)$ and $31.57 \%(90 / 285)$ for the Willis, Hoffman and centrifugal flotation techniques respectively. Although minimal, the differences reported here might be related to specific characteristics presented by each method.

Ancylostoma spp. eggs were the most frequently detected, followed those of Toxocara spp. and Trichuris spp. These results are similar to those obtained in a previous study in the state of Santa Catarina in which Dipylidium caninum, Toxocara canis and Trichuris vulpis were the most prevalent species [23].

The highest relative frequency was detected for Ancylostoma spp. (63.74\% to 88.76\%), in all the techniques used. On the other hand, Toxocara spp. was the most common parasite detected using the Hoffman technique $(35.77 \%)$, in contrast with the Willis and centrifugal flotation techniques, which both presented relative frequencies lower than $20 \%$. Differently from the other parasites, the relative frequencies of eggs of Trichuris spp. and Strongyloides spp. were lower than $1 \%$. The latter was detected only by means of centrifugal flotation. Interestingly, the high number of eggs detected in some samples (e.g. cases in which Toxocara spp. and Ancylostoma spp. presented 336 and 200 eggs, respectively, detected by means of centrifugal flotation) revealed that these samples presented severe parasitism and reinforces the importance of using these techniques in diagnosing parasitic helminths.

Considering the Willis technique to be the gold standard, sensitivity and specificity of $79 \%$ and $85 \%$, respectively, were achieved in diagnosing Ancylostoma spp., which was classified as "good" according to the kappa index (0.625). Conversely, the Hoffman technique presented a similar specificity value (89\%) but lower sensitivity $(54 \%)$.

The centrifugal flotation features concentration of eggs through several washes, thereby facilitating their identification. In this method, high sensitivity (80\%) and specificity (98\%) for detection of Toxocara spp. was observed. On the other hand, the Hoffman technique showed sensitivity and specificity of $67 \%$ and $100 \%$, respectively. For both of these tests, the kappa value of 0.48 was considered to be "fair", thus indicating the need to perform tests in parallel in order to improve the diagnosing of toxocarids.

In general, the Willis and centrifugal-flotation techniques showed good reproducibility; in addition both techniques detected higher numbers of eggs of Ancylostoma spp. and Toxocara spp. The differences in sensitivity and specificity between the techniques derive from the individual characteristics of each of them, which give rise to differences in sensitivity and/or specificity in relation to certain parasites [24]. In this context, it is recommended that examination of feces using more than one technique. Use of a single method may not reveal the real situation of parasitism, especially considering that in many cases, animals show mixed infections.

Table 3. Evaluation of the techniques of Modified Centrifugal-flotation and Spontaneous sedimentation of Hoffman, Pons and Janer in relation to the Willis-Mollay Floating technique (gold standard) for the diagnosis of intestinal parasites in canine fecal samples in the municipality of Garanhuns, PE.

\begin{tabular}{|c|c|c|c|c|c|c|}
\hline & \multicolumn{3}{|c|}{ Modified centrifugal flotation } & \multicolumn{3}{|c|}{$\begin{array}{c}\text { Spontaneous sedimentation of Hoffman, } \\
\text { Pons and Janer }\end{array}$} \\
\hline & Ancylostoma spp. & $\begin{array}{l}\text { Toxocara } \\
\text { spp. }\end{array}$ & Trichuris spp. & Ancylostoma spp. & $\begin{array}{l}\text { Toxocara } \\
\text { spp. }\end{array}$ & Trichuris spp. \\
\hline Sensitivity & $79.00 \%$ & $80.00 \%$ & $000.00 \%$ & $54.00 \%$ & $67.00 \%$ & $000.00 \%$ \\
\hline Specificity & $85.00 \%$ & $98.00 \%$ & $100.00 \%$ & $89.00 \%$ & $100.00 \%$ & $100.00 \%$ \\
\hline Predictive value $(+)$ & $80.00 \%$ & $73.00 \%$ & $000.00 \%$ & $76.00 \%$ & $100.00 \%$ & $000.00 \%$ \\
\hline Predictive value $(-)$ & $85.00 \%$ & $98.00 \%$ & $100.00 \%$ & $75.00 \%$ & $97.00 \%$ & $100.00 \%$ \\
\hline Accuracy & $83.00 \%$ & $96.00 \%$ & $99.00 \%$ & $75.00 \%$ & $97.00 \%$ & $99.00 \%$ \\
\hline
\end{tabular}




\section{Conclusion}

In conclusion, in order to obtain a reliable diagnosis, the centrifugal flotation method, which showed higher sensitivity for detecting Ancylostoma spp. and Toxocara spp. (the most common parasites in this study), could be used in association with the Willis technique within routine diagnostic laboratory analysis.

\section{References}

[1] Otranto, D. and Eberhard, M.L. (2011) Zoonotic Helminths Affecting the Human Eye. Parasites \& Vectors, 4, 41. http://dx.doi.org/10.1186/1756-3305-4-41

[2] Santarém, V.A., Giuffrida, R. and Zanin, G.A. (2004) Larva migrans cutânea: Ocorrência de casos humanos e identificação de larvas de Ancylostoma spp. em parque público do município de Taciba, São Paulo. Revista da Sociedade Brasileira de Medicina Tropical, 37, 179-181. http://dx.doi.org/10.1590/S0037-86822004000200014

[3] Hohlenwerger, M.C., Almeida, M.A.O., Silva, A., Carvalho, S.M.S., Schilling, A.C. and Munhoz, A.D. (2011) Larvas de Ancilostomatídeos em sedimentos de solo de praias de Salvador, Bahia. Revista Brasileira de Medicina Veterinária, 33, 111-114.

[4] Andresiuk, M.V., Denegri, G.M., Esardella, N.H. and Hollmann, P. (2003) Encuesta coproparasitológico canina realizado em plazas publicas de la cuidad de Mar del Plata. Bueno Aires, Argentina. Parasitología Latinoamericana, 58, 17-22. http://dx.doi.org/10.4067/S0717-77122003000100003

[5] Scaini, C.J., Tolado, R.N., Lovatel, R.R., Dionello, M.A., Gatti, F.A. and Susin, U.L. (2003) Contaminação ambiental por ovos e larvas de helmintos em fezes de cães na área central do Balneário cassino, Rio Grande do Sul. Revista da Sociedade Brasileira de Medicina Tropical, 36, 529-619. http://dx.doi.org/10.1590/S0037-86822003000500013

[6] Rey, L. (2008) Parasitologia: Parasitologia e Doenças Parasitárias do Homem nos Trópicos Ocidentais. 4th Edition, Guanabara Koogan, Rio de Janeiro.

[7] Menão, M.C., Faria, T.L.S.A., Almeida, J.M.S., Chiacchio, R.G. and Rocha, A. (2014) Pesquisa de infecções parasitárias com potencial zoonótico em animais mantidos em habitações coletivas. Atas de Saúde Ambiental, 2, 2-8.

[8] Santarém, V.A., Sartor, I.F. and Bergamo, F.M.M. (1998) Contamination by Toxocara spp. Eggs in Public Parks and Squares in Botucatu, São Paulo State, Brazil. Revista da Sociedade Brasileira de Medicina Tropical, 31, 529-532. http://dx.doi.org/10.1590/S0037-86821998000600004

[9] Blazius, R.D., Emerick, S., Prophiro, J.S., Romão, P.R.T. and Silva, O.S. (2005) Ocorrência de protozoários e helmintos em amostras de fezes de cães errantes da cidade de Itapema, Santa Catarina. Revista da Sociedade Brasileira de Medicina Tropical, 38, 73-74. http://dx.doi.org/10.1590/S0037-86822005000100018

[10] Campos Filho, P.C., Barros, L.M., Campos, J.O., Braga, V.B., Cazorla, I.M., Albuquerque, G.R. and Carvalho, S.M.S. (2008) Zoonotic Parasites in Dog Feces at Public Squares in the Municipality of Itabuna, Bahia, Brazil. Revista Brasileira de Parasitologia Veterinária, 17, 206-209.

[11] Mandarino-Pereira, A., de Souza, F.S., Lopes, C.W. and Pereira, M.J. (2010) Prevalence of Parasites in Soil and Dog Feces According to Diagnostic Tests. Veterinary Parasitology, 170, 176-181. http://dx.doi.org/10.1016/j.vetpar.2010.02.007

[12] Sprenger, L.K., Green, K.T. and Molento, M.B. (2014) Geohelminth Contamination of Public Areas and Epidemiological Risk Factors in Curitiba, Brazil. Revista Brasileira de Parasitologia Veterinária, 23, 69-73. http://dx.doi.org/10.1590/S1984-29612014009

[13] Núñez, F.A. (1999) Algunas consideraciones sobre el control de la calidad del diagnóstico de las parasitosis intestinales en América Latina. La Habana, 9, 257.

[14] Katagiri, S. and Oliveira-Sequeira, T.C.G. (2007) Zoonoses causadas por parasitas intestinais de cães e o problema do diagnóstico. Arquivos do Instituto Biológico, 74, 175-184.

[15] Papini, R., Campisi, E., Faggi, E., Pini, G. and Mancianti, F. (2012) Prevalence of Toxocara canis Eggs in Dog Faeces from Public Places of Florence, Italy. Helminthologia, 49, 154-158. http://dx.doi.org/10.2478/s11687-012-0031-0

[16] Willis, H.H. (1921) A Simple Levitation Method for the Detection of Hookworm Ova. Medical Journal of Australia, 2 , 375-376.

[17] Hoffman, W.A., Pons, J.A. and Janer, J.L. (1934) The Sedimentation Concentration Method in Schistosomiasis Mansoni. Puerto Rico Journal of Public Health and Tropical Medicine, 9, 283-289.

[18] Figueiredo, P.C., Serra-Freire, N.M. and Grisi, L. (1984) Eimerias de bovinos leiteiros no estado do Rio de Janeiro: Técnicas de diagnóstico e espécies identificadas. Atas da Sociedade de Biologia do Rio de Janeiro, 24, 22-26.

[19] Rey, L. (2002) Bases da Parasitologia Médica. 2nd Edition, Guanabara Koogan, Rio de Janeiro.

[20] Bowman, D.D. (2010) Georgis Parasitologia Veterinária. 9th Edition, Elsevier Brasil, São Paulo. 
[21] Landis, J.R. and Kock, G.G. (1977) The Measurement of Observer Agreement for Categorical Date. Biometrics, 33, 159-174. http://dx.doi.org/10.2307/2529310

[22] Cerqueira, E.J.L., Arcanjo, M.S. and Alcântara, L.M. (2007) Análise comparativa da sensibilidade da técnica de Willis no diagnóstico parasitológico da ancilostomíase. Dialogos \& Ciência, 5, 1-7.

[23] Mergener, D., Caricimo, A., Langer, D., Klein, D., Lima, G., Verona, J., et al. (2013) Enteroparasitos de cães errantes da zona urbana dos municípios de Água Doce, Irani, Joaçaba, Ponte Serrada e Treze Tílias, Santa Catarina, Brasil. Unoesc \& Ciência, 4, 127-134.

[24] Sloss, W.M., Zajac, M.A. and Kemp, R.L. (1999) Parasitologia clínica veterinária. Manole, São Paulo. 
Scientific Research Publishing (SCIRP) is one of the largest Open Access journal publishers. It is currently publishing more than 200 open access, online, peer-reviewed journals covering a wide range of academic disciplines. SCIRP serves the worldwide academic communities and contributes to the progress and application of science with its publication.

Other selected journals from SCIRP are listed as below. Submit your manuscript to us via either submit@scirp.org or Online Submission Portal.
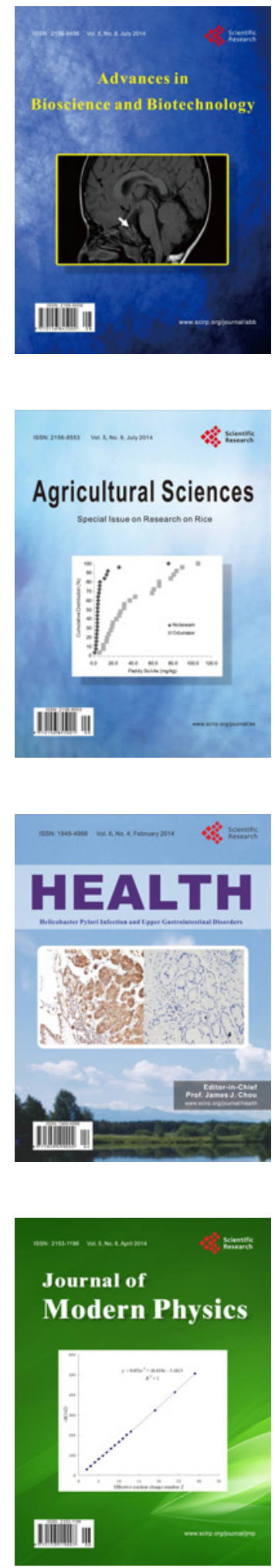
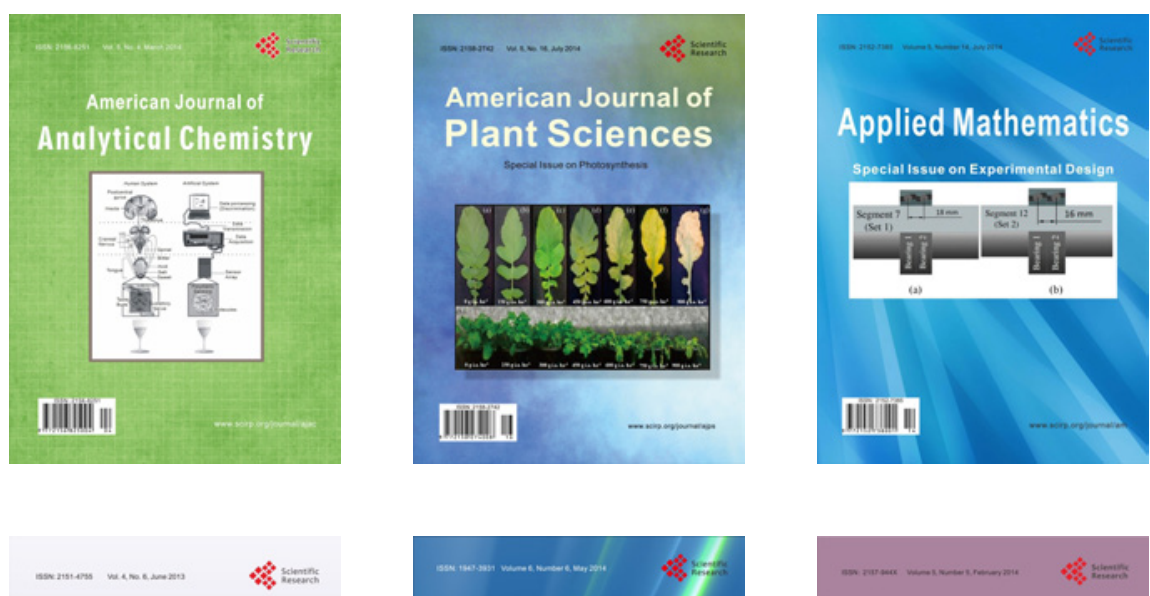

Creative Education
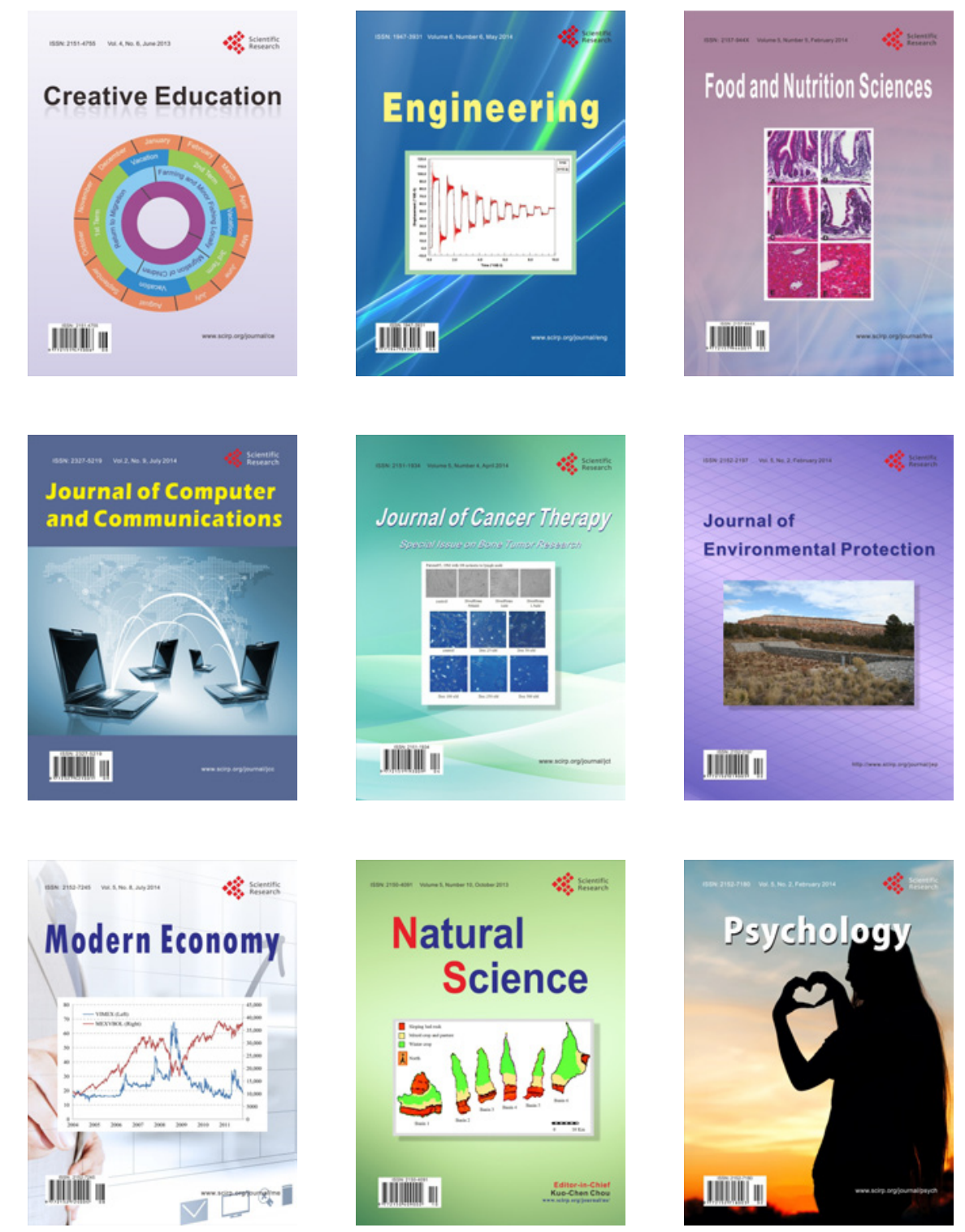